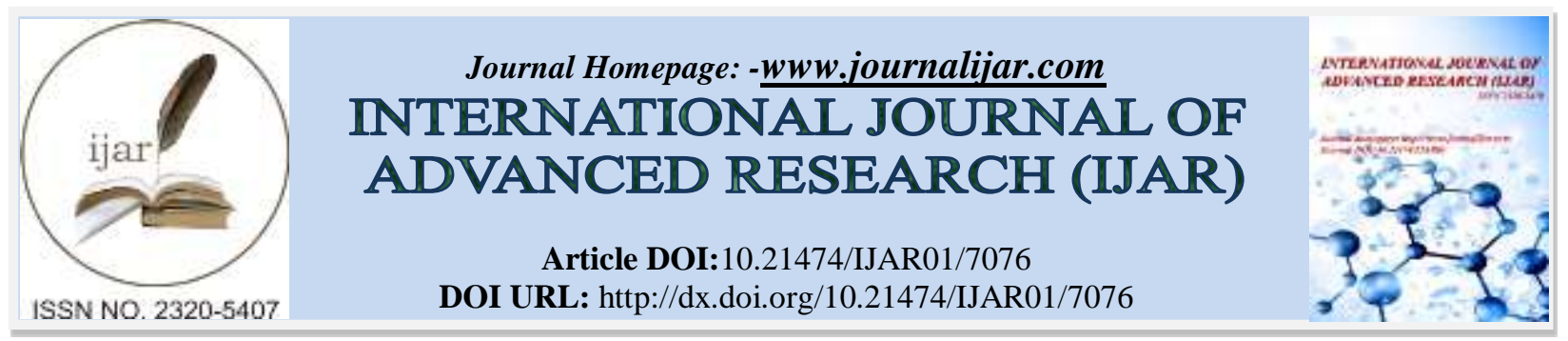

RESEARCH ARTICLE

\title{
QUALITY CHARACTERISTICS OF FUNCTIONAL SAUSAGE EMULSIFIED BY LOW FAT WITH SILKWORM POWDER AND SILKWORM CORDYCEPS.
}

\author{
Il-Suk Kim, Tae Wan Kim and Sam Woong Kim. \\ Swine Science and Technology Center, Gyeongnam National University of Science and Technology, Gyeongnam, \\ Jinju 52725, South Korea.
}

\section{Manuscript Info}

Manuscript History

Received: 11 March 2018

Final Accepted: 13 April 2018

Published: May 2018

Keywords:-

Functionality, Sausage, Silkworm, Silkworm Cordyceps, Storage.

\begin{abstract}
This study was done to prepare functional sausages using silkworm powder and silkworm cordyceps. The $\mathrm{pH}$ values of the treated groups were significantly higher than that of non-treated group $(\mathrm{p}<0.05)$. TBARS values were significantly increased in all the groups with storage period elapses $(\mathrm{p}<0.05)$. Since the TBARS value of the silkworm powder group was lower than those of the other groups, it was assumed that this group has antioxidative functionality for lipid. The degree of redness was significantly higher in silkworm powder group ( $\mathrm{p}<0.05$ ), whereas yellowness in those of silkworm powder and silkworm cordyceps groups was significantly lower than that of control group $(p<0.05)$. In the cohesiveness, the treated groups tended to be significantly lower with storage period elapses $(p<0.05)$. In the springiness, the silkworm powder group was significantly lower at the end of storage than at the beginning of storage $(p<0.05)$. Since total bacterial counts were significantly lower in silkworm powder and silkworm cordyceps groups than those of the control group, it was assumed that the treated groups have antimicrobial functions. As a result of sensory evaluation, meat color and aroma were significantly higher in control and silkworm powder groups, but there were no significant differences in flavor, tenderness, juiciness and overall acceptability ( $p>0.05$ ). Therefore, since functionality of the sausages were enhanced by the supplementations of silkworm powder and silkworm cordyceps, we suggest that the product is potentially useful as a functional sausage.
\end{abstract}

Copy Right, IJAR, 2018,. All rights reserved.

\section{Introduction:-}

Mulberry leaves, mulberry fruit, root husk, silk fibroin, and silkworm (Bombyx mori L.), which are products related with silk industry, have high added value as functional natural food materials. In particular, since silkworms have been maintained by high content of proteins, the larvae have been mainly used as food rather than medicines from ancient times (Kim et al., 2005). To date, studies on the physiological action of silkworm powder have been performed variously on the purposes of health functional food materials and their functional properties (Choi et al., 2003; Cha et al., 2010; Kim et al., 2017a and b; Park, et al., 2017). 
Medicinal mushrooms from insects are called cordyceps (Ji et al., 2003). Since it is difficult to obtain the raw material from natural sources due to very rare, many studies have been done by a number of researchers to develop a new type of cordyceps, which has a similar action (Kim et al., 2003; Cha et al., 2010; Kim et al., 2017a and b; Park, et al., 2017). It is well known that the functionalities of Cordyceps sinensis extracts have many effects such as improving immunity, suppressing stress, restoring fatigue, preventing biooxidation, inhibiting lipid peroxidation, liver protection and anti-cancer effect (Cha et al., 2010; Kim et al., 2017a and b; Park, et al., 2017).

As a result of the studies using silkworm powder and silkworm cordyceps as a new functional food, the powders are examined for the improvement of the quality of products via supplementation in diabetic beverage, bread, red pepper paste and doenjang (Choi et al., 2003; Kim et al., 2005; Lim et al., 2002; Park et al., 2003; Bang and Kim, 2003; Kwon, 2004). Therefore, this study was done to evaluate the quality as food products through the development of emulsified sausages with silkworm and silkworm cordyceps, and to introduce standard manuals for industrialization.

\section{Materials and Methods:-}

Production of functional sausage containing silkworm powder and silkworm cordyceps:-

The functional sausages were prepared by $0.4 \%$ of silkworm powder (SP $0.4 \%$ ) and silkworm cordyceps (SC $0.4 \%$ ), and non- additive (CTL 0\%) (Table 1). The product was prepared in accordance with manufacturing method of the emulsified sausage to generally use. Excess fat and connective tissues were removed from loin of American Berkshire, and the loin was ground in a $5 \mathrm{~mm}$ diameter. The crushed raw meat was transferred to the silent cutter and added according to mixing ratios while rotating at a low speed (Table 1). Ice water was used to prevent excessive temperature rise during the emulsification process. When the various kinds of additives were mixed and the myofibrillar protein was eluted sufficiently at high speed, fat was added and emulsified. The emulsified samples were filled in a non-breathable colored fibrous casing [ $\varnothing 46 \mathrm{~mm}$, Dongbang Trading Co., Ltd.], and was then treated at $78^{\circ} \mathrm{C}$ for $75 \mathrm{~min}$ in an autoclave (JS-AC-100, 100L, Johnsam Co., Korea). The treated samples were cooled in flowing cold water, vacuum-packed in PE film, and stored in a refrigerator at $5 \pm 1^{\circ} \mathrm{C}$ for 30 days. The fat replacer was added into product manufacture after prehydrolyhration at a ratio of 1: 0.5: 0.5: 10 by the soy protein isolate (SPI EX-33, Dupont Protein Technologies International, USA), carrageenan (WG, MSC Co., LTD, Korea), maltodextrin (MD-1520, Corn Products Korea, Inc., Korea) and water, respectively.

\section{pH, TBARS and VBN:-}

The value of $\mathrm{pH}$ was measured by a $\mathrm{pH}$ meter (8603, Metrohm, Swiss) after homogenization for 10 seconds at 13,500 rpm with a homogenizer (T25B, IKA Sdn. Bhd., Malaysia) after mixing with $10 \mathrm{~g}$ of sample and $90 \mathrm{~mL}$ of distilled water.

TBARS was measured by the method of Buege and Aust (1978). Briefly, the reaction mixture was prepared and homogenized by $5 \mathrm{~g}$ of the sample, $50 \mu \mathrm{l}$ of butylated hydroxyanisole (BHA) and $15 \mathrm{ml}$ of distilled water. An aliquot $(1 \mathrm{ml})$ of the homogenate was placed in a test tube, and the transferred aliquot was mixed with $2 \mathrm{ml}$ of thiobarbituric acid (TBA) / trichloroacetic acid (TCA). The treated solution was reacted in a water bath at $90^{\circ} \mathrm{C}$ for $15 \mathrm{~min}$, cooled, and then centrifuged at 3,000 rpm for $10 \mathrm{~min}$. The upper layer of the centrifuged sample was collected and absorbance was measured at $531 \mathrm{~nm}$. TBARS was calculated by the following equation.

$$
\text { TBARS }=\text { Absorbance value at } 531 \mathrm{~nm} \times 5.88
$$

VBN was measured by the method of Pearson (1968). Briefly, after homogenizing the mixture of $10 \mathrm{~g}$ chopped meat and $90 \mathrm{ml}$ distilled water, the homogenized solution was filtered with whatman No. 1, $1 \mathrm{ml}$ of the filtrate was added into out chamber of the conway unit, whereas $1 \mathrm{ml}$ of $0.01 \mathrm{~N}$ boric acid solution and $100 \mathrm{ul}$ of an indicator solution $(0.066 \%$ methyl red $+0.066 \%$ bromocresol green) were added into inner chamber of the conway unit. Glycerine was applied to the adhesion site of the conway unit with the lid, $1 \mathrm{ml}$ of $50 \% \mathrm{~K}_{2} \mathrm{CO}_{3}$ was injected into the outer chamber and then immediately sealed. The container was then stirred horizontally and incubated at $37{ }^{\circ} \mathrm{C}$ for 120 min. After incubation, the boric acid solution of the inner chamber was measured with $0.02 \mathrm{~N} \mathrm{H}_{2} \mathrm{SO}_{4}$. VBN was calculated by the following equation.

$$
\operatorname{VBN}(m g \%)=(a-b) \times f \times 0.02 \times 14.007 \times / S \times 100 \times 100
$$

a; sample ml, b; blank ml, S; sample wt, f; $0.02 \mathrm{~N} \mathrm{H}_{2} \mathrm{SO}_{4}$ factor 


\section{Shear force and texture:-}

Shear force was carried out using a knife-type plunger with a $5 \mathrm{~mm}$ diameter by laying down a cylindrical fresh meat $(\varnothing 1.8 \times 2.0 \mathrm{~cm})$ horizontally using Instron 3343 (US / MX50, A \& \& D Co., USA) as a shearing cutting test. The texture was measured by the using spherical plunger of adapter No. 5 with vertically cylindrical heated meat $(\varnothing 1.8 \times 2.0 \mathrm{~cm})$ as a mastication test. The analysis conditions were a chart speed of $120 \mathrm{~mm} / \mathrm{min}$, a maximum load of $10 \mathrm{~kg}$, and a measurement speed of $60 \mathrm{~mm} / \mathrm{min}$. The texture was measured by brittleness $(\mathrm{kg}), \mathrm{hardness}(\mathrm{kg})$, cohesiveness $(\%)$, springiness $(\mathrm{mm})$, gumminess $(\mathrm{kg})$ and chewiness $\left(\mathrm{kg} \mathrm{k}^{*} \mathrm{~mm}\right)$.

\section{Meat color:-}

Meat color was measured 5 times repeatedly in the same manner by a Chromameter (Minolta Co. CR 400, Japan). Deep meat color was performed by cutting the meat at 90 degrees and surface meat color was measured in the same manner to determine the $L^{*}$ value indicating the lightness, the $a^{*}$ value indicating the redness and the $b^{*}$ value indicating the yellowness. The standard color was standardized using a standard color plate with an $\mathrm{L}^{*}$ value of 89.2, $\mathrm{a}^{*}$ value of 0.921 , and a $\mathrm{b}^{*}$ value of 0.783 . Sausages were allowed to stand at room temperature for 5 min, and then the product was cut into $0.5 \mathrm{~cm}$ thick and measured for color.

Water activity, total bacterial counts and sensory evaluation:-

Water activity was measured at room temperature by a water activity meter $\left(\mathrm{O}_{2} \& \mathrm{CO}_{2}\right.$ analyzer LKM200A, Lokas, Korea). In order to determine the total number of bacteria, $10 \mathrm{~g}$ of sample was mixed with $90 \mathrm{ml}$ of $1 \%$ peptone, the mixture was homogenized with a bagmixer, and then an aliquot $(1 \mathrm{ml})$ was diluted with $9 \mathrm{ml}$ of peptone water. The diluted solution was plated on a plate counter agar (Difco), and the number of colonies were counted after incubation at $32^{\circ} \mathrm{C}$ for 2 days.

Sensory evaluation was done by 10 sensory test workers and by 9 point scale for each test. Sausages were analyzed for color, flavor, odor and overall acceptability after heating. 1 point marks extremely bad or slight, but 9 point marks extremely good or much.

\section{Statistical analysis:-}

The results obtained from the above tests were analyzed by the GLM (General Linear Model) method of SAS (1999) and Duncan's Multiple Range Test was used for the comparison of the treatment averages.

Table 1:-Formula of functional sausage

\begin{tabular}{|l|c|c|c|}
\hline \multirow{2}{*}{ Raw material } & \multicolumn{3}{|c|}{ Treatment $^{\text {() }}$} \\
\cline { 2 - 4 } & CTL 0\% & SP 0.4\% & SC 0.4\% \\
\hline Berkshire loin $_{\text {Fat replacer }}^{2)}$ & 71.57 & 71.57 & 71.57 \\
\hline Olive oil $^{\text {2) }}$ & 15.00 & 15.00 & 15.00 \\
\hline NPS $^{3)}$ & 1.50 & 1.50 & 1.50 \\
\hline Phosphate salt & 1.30 & 1.30 & 0.20 \\
\hline Sugar & 0.20 & 0.20 & 0.50 \\
\hline MSG & 0.50 & 0.50 & 0.05 \\
\hline Spice & 0.05 & 0.05 & 0.5 \\
\hline Ice water & 0.5 & 0.5 & 8.98 \\
\hline Silkworm powder & 9.38 & 8.98 & - \\
\hline Tilkworm Cordyceps & - & 0.4 & 0.4 \\
\hline
\end{tabular}

1. CTL (Control; non-treated), SP $0.4 \%$ (treated with $0.4 \%$ silkworm powder), SC $0.4 \%$ (treated with $0.4 \%$ silkworm cordyceps; Cordyceps militaris).

2. Prehydrated Fat replacer (ISP : Carrageenan : Maltodextrin : Water $=1: 0.5: 0.5: 10$ ).

3. $\mathrm{NPS}\left(\mathrm{NaCl}: \mathrm{NaNO}_{2}=99: 1\right)$. 
Table 2:-Change in $\mathrm{pH}$ during storage

\begin{tabular}{|l|c|c|c|}
\hline \multirow{2}{*}{ Treatments $^{1)}$} & \multicolumn{3}{|c|}{ Storage (day) } \\
\cline { 2 - 4 } & $\mathbf{1}$ & $\mathbf{1 5}$ & $\mathbf{3 0}$ \\
\hline CTL 0\% & $6.28 \pm 0.09^{\mathrm{Aa}}$ & $6.27 \pm 0.04^{\mathrm{Aa}}$ & $6.12 \pm 0.03^{\mathrm{Ba}}$ \\
\hline SP 0.4\% $0.4 \%$ & $6.02 \pm 0.03^{\mathrm{Bb}}$ & $6.08 \pm 0.03^{\mathrm{Ac}}$ & $5.95 \pm 0.02^{\mathrm{Cc}}$ \\
\hline
\end{tabular}

${ }^{1)}$ Treatments are the same as in Table 1.

${ }^{a, b, c}$ Means \pm SD with different superscripts in the same column significantly differ at $\mathrm{p}<0.05$.

${ }^{\mathrm{A}, \mathrm{B}}$ Means $\pm \mathrm{SD}$ with different superscripts in the same row significantly differ at $\mathrm{p}<0.05$.

Table 3:-Lipid peroxidation during storage

\begin{tabular}{|l|c|c|c|}
\hline \multirow{2}{*}{ Treatments $^{1)}$} & \multicolumn{3}{|c|}{ Storage (day) } \\
\cline { 2 - 4 } & $\mathbf{1}$ & $\mathbf{1 5}$ & $\mathbf{3 0}$ \\
\hline CTL 0\% & $0.10 \pm 0.01^{\mathrm{C}}$ & $0.39 \pm 0.05^{\mathrm{Bb}}$ & $0.62 \pm 0.08^{\mathrm{Ab}}$ \\
\hline SC 0.4\% & $0.14 \pm 0.01^{\mathrm{C}}$ & $0.57 \pm 0.08^{\mathrm{Ba}}$ & $0.87 \pm 0.19^{\mathrm{Aa}}$ \\
\hline
\end{tabular}

${ }^{1)}$ Thiobarbituric acid reactive substance (malonaldehyde $\mathrm{mg} / \mathrm{kg}$ ).

${ }^{2)}$ Treatments are the same as in Table 1.

${ }_{a, b, c}$ Means \pm SD with different superscripts in the same column significantly differ at $p<0.05$.

${ }^{\mathrm{A}, \mathrm{B}}$ Means \pm SD with different superscripts in the same row significantly differ at $\mathrm{p}<0.05$.

Table 4:-Meat colors during storage

\begin{tabular}{|c|c|c|c|c|}
\hline \multirow{2}{*}{$\begin{array}{l}\text { meat } \\
\text { color }\end{array}$} & \multirow[t]{2}{*}{ Treatments $^{1)}$} & \multicolumn{3}{|c|}{ Storage (day) } \\
\hline & & 1 & 15 & 30 \\
\hline \multirow[t]{3}{*}{$\mathrm{L}^{*}$} & CTL 0\% & $77.20 \pm 0.61^{\mathrm{a}}$ & $76.32 \pm 1.11^{\mathrm{a}}$ & $75.65 \pm 0.91^{\mathrm{a}}$ \\
\hline & SP $0.4 \%$ & $72.63 \pm 0.24^{\mathrm{Ac}}$ & $72.42 \pm 0.18^{\mathrm{ABab}}$ & $72.03 \pm 0.34^{\mathrm{Bb}}$ \\
\hline & SC $0.4 \%$ & $74.66 \pm 0.34^{b}$ & $69.52 \pm 4.80^{b}$ & $70.58 \pm 0.20^{c}$ \\
\hline \multirow[t]{3}{*}{$a^{*}$} & CTL 0\% & $10.67 \pm 0.09^{\mathrm{Ab}}$ & $10.29 \pm 0.38^{\mathrm{Ab}}$ & $10.54 \pm 0.13^{\mathrm{Bb}}$ \\
\hline & SP $0.4 \%$ & $12.42 \pm 0.47^{\mathrm{Aa}}$ & $12.39 \pm 0.29^{\mathrm{Aa}}$ & $11.91 \pm 0.14^{\mathrm{Ba}}$ \\
\hline & SC $0.4 \%$ & $10.79 \pm 0.20^{b}$ & $9.25 \pm 1.06^{b}$ & $9.53 \pm 0.09^{b}$ \\
\hline \multirow[t]{3}{*}{$b^{*}$} & CTL 0\% & $4.63 \pm 0.36^{c}$ & $5.35 \pm 1.00^{b}$ & $4.47 \pm 0.52^{b}$ \\
\hline & SP $0.4 \%$ & $9.98 \pm 0.40^{\mathrm{a}}$ & $9.99 \pm 0.13^{\mathrm{a}}$ & $10.27 \pm 0.29^{\mathrm{a}}$ \\
\hline & SC $0.4 \%$ & $7.40 \pm 0.59^{b}$ & $10.16 \pm 2.12^{\mathrm{a}}$ & $9.57 \pm 1.55^{\mathrm{a}}$ \\
\hline
\end{tabular}

1) Treatments are the same as in Table 1.

${ }^{a, b, c}$ Means \pm SD with different superscripts in the same column significantly differ at $p<0.05$.

${ }^{\mathrm{A}, \mathrm{B}}$ Means \pm SD with different superscripts in the same row significantly differ at $\mathrm{p}<0.05$.

Table 5:-Texture profile during storage

\begin{tabular}{|c|c|c|c|c|}
\hline \multirow[t]{2}{*}{ Texture } & \multirow[t]{2}{*}{ Treatments $^{1)}$} & \multicolumn{3}{|c|}{ Storage (day) } \\
\hline & & 1 & 15 & 30 \\
\hline \multirow{3}{*}{$\begin{array}{l}\text { Brittleness } \\
\text { (g) }\end{array}$} & CTL 0\% & $0.27 \pm 0.03^{b}$ & $0.28 \pm 0.12$ & $0.31 \pm 0.10$ \\
\hline & SP $0.4 \%$ & $0.36 \pm 0.01^{\mathrm{a}}$ & $0.40 \pm 0.09$ & $0.40 \pm 0.11$ \\
\hline & SC $0.4 \%$ & $0.37 \pm 0.06^{\mathrm{a}}$ & $0.38 \pm 0.04$ & $0.31 \pm 0.15$ \\
\hline \multirow{3}{*}{$\begin{array}{l}\text { Hardness } \\
\text { (kg) }\end{array}$} & CTL 0\% & $0.40 \pm 0.05$ & $0.35 \pm 0.05$ & $0.38 \pm 0.05$ \\
\hline & SP $0.4 \%$ & $0.36 \pm 0.01$ & $0.42 \pm 0.06$ & $0.48 \pm 0.17$ \\
\hline & $\mathrm{SC} 0.4 \%$ & $0.40 \pm 0.04$ & $0.40 \pm 0.05$ & $0.42 \pm 0.16$ \\
\hline \multirow{3}{*}{$\begin{array}{l}\text { Cohesiveness } \\
(\%)\end{array}$} & CTL 0\% & $65.11 \pm 7.18$ & $51.60 \pm 7.18$ & $54.94 \pm 5.75$ \\
\hline & SP $0.4 \%$ & $54.24 \pm 7.25^{\mathrm{A}}$ & $47.67 \pm 1.77^{\mathrm{AB}}$ & $42.84 \pm 5.58^{\mathrm{B}}$ \\
\hline & SC $0.4 \%$ & $57.77 \pm 2.84^{\mathrm{A}}$ & $44.85 \pm 7.60^{\mathrm{B}}$ & $50.78 \pm 6.82^{\mathrm{AB}}$ \\
\hline \multirow{3}{*}{$\begin{array}{l}\text { Springiness } \\
(\mathrm{mm})\end{array}$} & CTL 0\% & $13.06 \pm 0.07$ & $12.19 \pm 2.11$ & $13.19 \pm 0.59$ \\
\hline & SP $0.4 \%$ & $13.03 \pm 0.42^{\mathrm{AB}}$ & $13.44 \pm 0.18^{\mathrm{A}}$ & $11.27 \pm 1.69^{\mathrm{B}}$ \\
\hline & $\mathrm{SC} 0.4 \%$ & $12.91 \pm 0.22$ & $12.32 \pm 0.28$ & $11.82 \pm 1.03$ \\
\hline \multirow{2}{*}{$\begin{array}{l}\text { Gumminess } \\
\text { (g) }\end{array}$} & CTL 0\% & $25.57 \pm 0.96^{\mathrm{Aa}}$ & $18.12 \pm 3.13^{\mathrm{B}}$ & $20.62 \pm 1.27^{\mathrm{B}}$ \\
\hline & SP $0.4 \%$ & $19.55 \pm 2.14^{b}$ & $19.85 \pm 3.34$ & $20.68 \pm 6.78$ \\
\hline
\end{tabular}




\begin{tabular}{|l|l|c|c|c|}
\hline & SC 0.4\% & $22.92 \pm 1.62^{\mathrm{a}}$ & $18.32 \pm 5.27$ & $20.50 \pm 6.18$ \\
\hline \multirow{3}{*}{$\begin{array}{l}\text { Chewiness } \\
\text { (g) }\end{array}$} & CTL 0\% & $334.01 \pm 13.18^{\mathrm{Aa}}$ & $220.40 \pm 54.52^{\mathrm{B}}$ & $271.97 \pm 18.54^{\mathrm{AB}}$ \\
\cline { 2 - 5 } & SP 0.4\% & $254.88 \pm 31.58^{\mathrm{b}}$ & $266.92 \pm 45.51$ & $233.20 \pm 84.98$ \\
\cline { 2 - 5 } & SC 0.4\% & $295.64 \pm 15.87^{\mathrm{ab}}$ & $225.91 \pm 66.33$ & $245.91 \pm 92.95$ \\
\hline
\end{tabular}

${ }^{1)}$ Treatments are the same as in Table 1.

${ }^{a, b, c}$ Means \pm SD with different superscripts in the same column significantly differ at $\mathrm{p}<0.05$.

${ }^{\mathrm{A}, \mathrm{B}}$ Means \pm SD with different superscripts in the same row significantly differ at $\mathrm{p}<0.05$.

Table 6:-Total bacterial count $\left(\log 10 \mathrm{CFU} / \mathrm{cm}^{2}\right)$ during storage

\begin{tabular}{|l|c|c|c|}
\hline \multirow{2}{*}{ Treatments $^{1)}$} & \multicolumn{3}{|c|}{ Storage (day) } \\
\cline { 2 - 4 } & $\mathbf{1}$ & $\mathbf{1 5}$ & $\mathbf{3 0}$ \\
\hline CTL 0\% & $2.65 \pm 0.52^{\mathrm{B}}$ & $3.89 \pm 0.15^{\text {Aa }}$ & $3.99 \pm 0.07^{\text {Aa }}$ \\
\hline SC 0.4\% & $2.50 \pm 0.71$ & $3.64 \pm 0.74^{\text {ab }}$ & $3.69 \pm 0.24^{\text {ab }}$ \\
\hline
\end{tabular}

${ }^{1)}$ Treatments are the same as in Table 1.

${ }^{a, b, c}$ Means \pm SD with different superscripts in the same column significantly differ at $p<0.05$.

${ }^{\mathrm{A}, \mathrm{B}}$ Means \pm SD with different superscripts in the same row significantly differ at $\mathrm{p}<0.05$.

Table 7:-Sensory score during storage

\begin{tabular}{|c|c|c|c|c|}
\hline \multirow{2}{*}{ Sensory factor } & \multirow{2}{*}{ Treatments $^{2)}$} & \multicolumn{3}{|c|}{ Storage (day) } \\
\hline & & 1 & 15 & 30 \\
\hline \multirow[t]{3}{*}{ Color } & CTL 0\% & $6.33 \pm 0.52^{\mathrm{Aa}}$ & $5.83 \pm 0.41^{\mathrm{ABa}}$ & $5.33 \pm 0.82^{\mathrm{B}}$ \\
\hline & SP $0.4 \%$ & $5.17 \pm 0.75^{b}$ & $5.00 \pm 0.63^{\mathrm{b}}$ & $4.67 \pm 0.82$ \\
\hline & SC $0.4 \%$ & $5.50 \pm 0.55^{\mathrm{b}}$ & $5.17 \pm 0.41^{b}$ & $5.00 \pm 0.63$ \\
\hline \multirow[t]{3}{*}{ Aroma } & CTL 0\% & $5.17 \pm 0.75^{b}$ & $5.00 \pm 0.89^{\mathrm{ab}}$ & $4.67 \pm 0.82$ \\
\hline & SP $0.4 \%$ & $6.33 \pm 0.52^{\mathrm{Aa}}$ & $5.50 \pm 0.55^{\mathrm{Ba}}$ & $4.83 \pm 0.75^{\mathrm{B}}$ \\
\hline & SC $0.4 \%$ & $5.17 \pm 0.75^{\mathrm{Ab}}$ & $4.50 \pm 0.55^{\mathrm{ABb}}$ & $4.33 \pm 0.52^{B}$ \\
\hline \multirow[t]{3}{*}{ Flavor } & CTL 0\% & $5.67 \pm 0.82^{\mathrm{A}}$ & $5.00 \pm 0.63^{\mathrm{AB}}$ & $4.50 \pm 0.55^{\mathrm{B}}$ \\
\hline & SP $0.4 \%$ & $5.83 \pm 0.75^{\mathrm{A}}$ & $4.83 \pm 0.41^{B}$ & $4.50 \pm 0.55^{\mathrm{B}}$ \\
\hline & SC $0.4 \%$ & $6.33 \pm 0.52^{A}$ & $5.50 \pm 0.55^{\mathrm{B}}$ & $5.00 \pm 0.63^{B}$ \\
\hline \multirow[t]{3}{*}{ Tenderness } & CTL 0\% & $5.17 \pm 0.75$ & $4.83 \pm 0.75$ & $4.67 \pm 0.82$ \\
\hline & SP $0.4 \%$ & $5.33 \pm 0.82$ & $5.17 \pm 0.75$ & $4.83 \pm 0.75$ \\
\hline & SC $0.4 \%$ & $5.50 \pm 0.55$ & $5.17 \pm 0.75$ & $4.83 \pm 0.75$ \\
\hline \multirow[t]{3}{*}{ Juiciness } & CTL $0 \%$ & $6.17 \pm 0.75^{\mathrm{A}}$ & $5.50 \pm 0.55^{\mathrm{AB}}$ & $5.00 \pm 0.63^{B}$ \\
\hline & SP $0.4 \%$ & $5.33 \pm 0.52^{\mathrm{A}}$ & $4.83 \pm 0.75^{\mathrm{AB}}$ & $4.50 \pm 0.55^{\mathrm{B}}$ \\
\hline & SC $0.4 \%$ & $5.83 \pm 0.98^{\mathrm{A}}$ & $5.00 \pm 1.10^{\mathrm{AB}}$ & $4.50 \pm 0.84^{\mathrm{B}}$ \\
\hline \multirow{3}{*}{$\begin{array}{l}\text { Overall } \\
\text { acceptability }\end{array}$} & CTL 0\% & $5.70 \pm 0.24^{\mathrm{A}}$ & $5.23 \pm 0.15^{\mathrm{B}}$ & $4.83 \pm 0.34^{B}$ \\
\hline & SP $0.4 \%$ & $5.60 \pm 0.18^{A}$ & $5.07 \pm 0.24^{\mathrm{B}}$ & $4.67 \pm 0.21^{\mathrm{B}}$ \\
\hline & SC $0.4 \%$ & $5.67 \pm 0.47^{\mathrm{A}}$ & $5.07 \pm 0.39^{\mathrm{AB}}$ & $4.73 \pm 0.47^{\mathrm{B}}$ \\
\hline
\end{tabular}

${ }^{1)}$ Sensory scores were assessed on 9 point scale base on 1=extremely bad or slight, 9=extremely good or much.

${ }^{2)}$ Treatments are the same as in Table 1.

${ }_{a, b, c}$ Means \pm SD with different superscripts in the same column significantly differ at $\mathrm{p}<0.05$.

${ }^{\mathrm{A}, \mathrm{B}}$ Means \pm SD with different superscripts in the same row significantly differ at $\mathrm{p}<0.05$.

\section{Results and Discussion:-}

PH characteristics of functional sausages:-

Table 2 shows changes in $\mathrm{pH}$ during storage of low fat-emulsified functional sausages supplemented with silkworm powder and silkworm cordyceps. The $\mathrm{pH}$ of meat products varies depending on the ratio of raw meat and additives, and affects quality changes such as freshness, water holding capacity, meat color, and texture (Miller et al., 1980). In this study, $\mathrm{pH}$ was significantly lowered at 30 days of storage at all the groups $(\mathrm{p}<0.05)$ when compared to the early days of storage. These results are consistent with the results that the $\mathrm{pH}$ of sausage decreases with storage period elapse regardless of storage temperature (Kim et al., 2000). The $\mathrm{pH}$ value of the control group was significantly higher than those of the treated groups ( $\mathrm{p}<0.05$ ), but was no significant difference between SP $0.4 \%$ and SC $0.4 \%$ groups $(\mathrm{p}>0.05)$. In low fat sausages, sodium lactate or grapefruit seed extract and fat replacer had no specific 
effects on water holding capacity, purge loss and texture (Chin et al., 2005; Fernandez-Diez et al., 2016). On the other hand, $\mathrm{pH}$ during the storage period is increased due to the decomposition of the amino acid and exposure of the basic group, or the $\mathrm{pH}$ is increased due to the change of protein, decrease of electrolytic dissociation and ammonia formation (Deymer and Vendekerckhov, 1979). However, since $\mathrm{pH}$ was decreased in this study, Systematic research is needed to clarify this phenomenon.

\section{Fatty acid peroxidation of functional sausages:-}

Table 3 shows changes in fatty acid peroxidation (TBARS) during storage of low fat-emulsified functional sausages containing silkworm powder and silkworm cordyceps. Thiobarbituric acid reactive substances (TBARS) have been proposed to measure the degree of autoxidation of fat-containing foods and is the most widely used method to measure the fat oxidation state of food (Tarladgis et al., 1960; Melton, 1983). The results of TBA analysis are expressed as mg of malonaldehyde (MA), a degradation product of lipid peroxides in $1 \mathrm{~kg}$ of muscle (Melton, 1983). Unsaturated fatty acids present in living organisms and foods, damage proteins and DNA, cause mutations and cancer, promote arteriosclerosis and aging, and deteriorate food quality as easily oxidized to produce peroxides such as hydrogen peroxide. In addition, the production of TBARS due to the rancidity of meat products is closely related to the formation of spoilage, and the content of TBARS is an index for evaluating the freshness of meat products (Rogar and Robert, 1971). Furthermore, TBARS values were significantly increased in all treatments with storage period elapse $(\mathrm{p}<0.05)$.

In this study, the content of TBARS was increased with the passage of storage period. This tendency is consistent with the results of the previous studies on sausages (Fista et al., 2004; Kim et al., 2002; Magra et al., 2006; do Amaral et al., 2015). Although there was no difference between the treated groups ( $\mathrm{p}>0.05$ ), since the TBARS value of silkworm cordyceps group was slightly lower than those of the other groups, it is suggested that further study is performed for the effect on inhibition of fatty acid peroxidation according to additional amount of silkworm cordyceps. When sausage is prepared by adding green tea powder, TBARS values are decreased (Choi et al., 2003). These antioxidative activities of green tea inhibit the peroxidation of unsaturated fatty acids by reactive oxygen species and have a blocking effect against metal ions, mainly due to the involvement of catechin, a polyphenol compound of green tea.

\section{Change of meat color in functional sausages:-}

Table 4 shows changes in meat color during storage of low fat-emulsified functional sausages containing silkworm powder and silkworm cordyceps. Meat color is determined by myoglobin in fresh meat. Myoglobin is brown when it is denatured by heating, but the meat products to undergo curing process are fixed in red color even when heated. The color of meat products is an important factor in selecting meat products by consumers. In the case of heated meat products, consumers prefer bright color and distinctive pink color (Cáceres et al., 2004). As the storage period was longer, $\mathrm{L}^{*}$ value of lightness was not significantly different between control and silkworm cordyceps ( $\left.\mathrm{p}>0.05\right)$, but the addition of silkworm powder increased significantly with storage period $(\mathrm{p}<0.05)$. The $\mathrm{a}^{*}$ value of redness was significantly decreased in the control and silkworm powder groups $(\mathrm{p}<0.05)$, but did not change with storage period in silkworm cordyceps group $(\mathrm{p}>0.05)$. The $\mathrm{b}^{*}$ value indicating yellowness was not significantly increased in all treatments $(p>0.05)$. The lightness was significantly higher in the control group than in the treated groups ( $p$ $<0.05)$, but redness was significantly higher in the silkworm powder group $(\mathrm{p}<0.05)$. Yellowness was significantly lower in control than in the treated groups $(\mathrm{p}<0.05)$.

\section{Texture characteristics of functional sausages:-}

Table 5 shows changes in the texture properties of low fat-emulsified functional sausages containing silkworm powder and silkworm cordyceps during storage. Measurement of texture for meat products is one of the important methods for measuring the physical properties of meat. The texture characteristics of meat products are influenced by various factors such as mixing ratio, protein functionality, fat content and characteristic difference (Cavestany et al., 1994). The hardness and brittleness indicating the force required to modify the material over the storage period were not significantly different in all the groups ( $p>0.05$ ). In addition, there was no significant difference in gumminess and chewiness between silkworm powder and silkworm cordyceps groups $(\mathrm{p}<0.05)$. The cohesiveness indicating the force necessary for the internal binding of the food form was not significantly different in control group, but the treated groups tended to be significantly lower with storage period $(\mathrm{p}<0.05)$. There was no significant difference in springiness between control and silkworm cordyceps groups ( $>>0.05)$, but silkworm powder group was significantly lower at the end of storage $(\mathrm{p}<0.05)$. There were significant differences in brittleness, gumminess, and chewiness $(\mathrm{p}<0.05)$ at the 1 st day of storage, but were no significant differences thereafter. The other texture 
properties were no significant difference between the early stages and the end of storage ( $p>0.05)$. Therefore, it was concluded that the addition of silkworm and silkworm cordyceps did not affect the tissue characteristics.

\section{Changes in total bacterial counts and sensory evaluation of functional sausages:-}

Table 6 shows changes in total bacterial counts during storage of low fat-emulsified functional sausages containing silkworm powder and silkworm cordyceps. The measurement of total bacterial counts is a criterion for determining the suitability of overall microbial contamination and sanitary handling. In this study, the total number of bacteria $\left(\log 10 \mathrm{CFU} / \mathrm{cm}^{2}\right)$ in the control group was significantly increased from 2.65 to 3.99 at the end of storage (p $\left.<0.05\right)$, but were no difference between the treated groups $(p>0.05)$. Since the number of microorganisms in the treated groups were significantly lower than that of the control, the silkworm powder and silkworm cordyceps were found to have antimicrobial function. Especially, the number of microorganisms in the silkworm cordyceps group were 2.85 at the 30 day of storage, which was significantly lower than other groups ( $p>0.05$ ).

If the number of bacteria in the sausage is $10^{8} \mathrm{CFU} / \mathrm{g}$, odor of spoilage can result and not be edible (Lamkey et al., 1991). To date, sausages of pine needle and green tea extract have antibacterial activity up to 3 days of storage compared to control (Kim et al., 2002). Since the antimicrobial activity is detected from the herb extract, rosemary extract and garlic extract (del Campo et al., 2000; Fernández-López et al., 2005; Nuutila et al., 2003; Park et al., 2005), it is suggested that studies on the effect of storage period extension of sausage carry out through application of these natural substances.

Table 7 shows the sensory evaluation results of low fat-emulsified functional sausages containing silkworm powder and silkworm cordyceps during storage. As a sensory evaluation, meat color and aroma had a higher score in the control and the silkworm powder groups, respectively, but flavor, tenderness, juiciness and overall acceptability were no significant differences ( $p>0.05)$.

In summary, since the sausage added with silkworm powder and silkworm cordyceps were identified to have functional properties, it is suggested that these products are highly applicable to functional food products.

\section{Acknowledgments:-}

This work was supported by Priority Research Centers Program through the National Research Foundation of Korea (NRF) funded by the Ministry of Education (2009-0093813).

\section{References:-}

1. Bang, H. Y. and Kim, G. H. 2003. A study on the quality characteristics of Doenjang prepared with Paecilomyces japonica, from silk. Korean J. Soc. Food Cookery Sci. 19, 694-700.

2. Buege, J. A. and Aust, J. D. 1978. Microsomal lipid peroxidation. Methods Enzymol. 52, 302-309.

3. Cha, J. Y., Kim, Y. S., Kang P. D., Ahn H. Y., Eom, K. E. and Cho, Y. S. 2010. Biological Activity and Chemical Characteristics of Fermented Silkworm Powder by Mold. J. Life Science. 20 (2), 237-244.

4. Chin, K. B., Kim, W, Y. and Kim, K. H. 2005. Physicochemical and textural properties, and antimicrobial effects of low-fat comminuted manufactured with grapefruit seed extract. Kor. J. Food Sci. Ani. Resour. 25, 141-148.

5. Choi, J. H., Kim, D. I., Park, S. H., Baek, S. J., Kim, N. J. and Ryu, K. S. 2003. Deveolment anti-diabetes drink using with silkworm (Bombyx mori L.) extract. Korean J. Seric. Sci. 45, 96-102.

6. Choi, S. H., Kwon H. C., An D. J., Park, J. R. and Oh, D. H. 2003. Nitrite contents and storage properties of sausage added with green tea powder. Korean J. Food Sci. Ani. Resour. 23 (4), 299-308.

7. del Campo, J., Amiot, M. J. and Nguyen-The, C. 2000. Antimicrobial effect of rosemary extracts. J. Food Protection. 63, 1359-1368.

8. do Amaral, D. S., Cardelle-Cobas, A., do Nascimento, B. M., Monteiro, M. J., Madruga, M. S. and Pintado, M. M. 2015. Development of a low fat fresh pork sausage based on chitosan with health claims: impact on the quality, functionality and shelf-life. Food Funct. 6 (8), 2768-2778.

9. Fernandez-Diez, A., Caro, I., Castro, A., Salvá, B. K., Ramos, D. D. and Mateo, J. 2016. Partial Fat Replacement by Boiled Quinoa on the Quality Characteristics of a Dry-Cured Sausage. J Food Sci. 81 (8), C1891-1898.

10. Fernández-López, J., Zhi, N., Aleson-Carbonell, L., Pérez-Alvarez, J. A. and Kuri, V. 2005. Antioxidant and antibacterial activities of natural extracts: application in beef meatballs. Meat Sci. 69, 371-380. 
11. Fista, G. A., Bloukas, J. G. and Siomos, A. S. 2004. Effect of leek and onion on processing and quality characteristics of Greek traditional sausages. Meat Sci. 68, 163-172.

12. Kim, C. J., Jeong, J. Y., Lee, E. S. and Song, H. H. 2002. Studies on improvement of quality and shelf-life of traditional marinated beef (Galbi) as affected by packaging method during storage at $-1^{\circ} \mathrm{C}$. Korean J. Food Sci. Technol. 34, 792-798.

13. Kim, M. W., Ahn, M. S. and Lim, Y. H. 2005. Quality characteristics of chicken patties with added mulberry leaves powder. Korean J. Food Cookery Sci. 21, 459-465.

14. Kim, S. M., Cho, Y. S., Yang, T. M., Lee, S. H., Kim, D. G. and Sung, S. K. 2000. Development of functional sausage using extracts from Schizandra chinensis. Kor. J. Food Sci. Ani. Resour. 20, 272-281.

15. Kim, T. H., Ahn, H. Y., Kim Y. W., Sim, S. Y., Seo, K. Il. and Cho, Y. S. 2017a. Biological Activity and Biochemical Properties of Water Extracts from Bacillus subtilis-fermented Silkworm (Bombyx mori L.) Powder by Origin. 27 (12), 1470-1478.

16. Kim, T. H., Ahn, H. Y., Kim Y. W., Sim, S. Y., Cho, H. D., Kim, M. D. and Cho, Y. S. $2017 \mathrm{~b}$. Hepatoprotective Effect of Bacillus subtilis-fermented Silkworm (Bombyx mori L.) Extract on Non-alcoholic Fatty Liver in Rats. 27 (9), 1031-1039.

17. Kwon, D. J. 2004. Quality improvement of Kochujang using Cordyceps sp. Korean J. Food Sci. Technol. 36, 81-85.

18. Lim, Y. H., Kim, M. W., Kim, A. J. and Kim, M. H. 2002. Effects of adding silkworm powder on the quality of Seolgiddeok. Korean J. Soc. Food Cookery Sci. 18, 562-566.

19. Magra, T. I., Bloukas, J. G. and Fista, G. A. 2006. Effect of frozen and dried leek on processing and quality characteristics of Greek traditional sausages. Meat Sci. 72, 280-287.

20. Melton, S. L. 1983. Methodology for following lipid oxidation in muscle foods. Food Technol. 37, 105-109.

21. Miller, A. J., Ackerman, S. A. and Palumbo, S. A. 1980. Effect of frozen storage on functionality of meat for processing. J. Food Sci. 45, 1466-1468.

22. Nuutila, A. M., Puupponen-Pimiä, R., Aarni, M. and Oksman-Caldentey, K. M. 2003. Comparison of antioxidant activities of onion and garlic extracts by inhibition of lipid peroxidation and radical scavenging activity. Food Chemistry. 81, 485-493.

23. Park, G. S., Youn, K. S., Hwang, S. H., Cho, H. J. and Kim, J. S. 2003. Optimization for the preparation of Jeung-pyun, with added Paeciomyces japonica powder, using a response surface methodology. Korean J. Soc. Food Cookery Sci. 19, 504-510.

24. Park, J. H. and Lee, K. H. 2005. Quality characteristics of beef jerky made with beef meat of various places of origin. Korean J. Food Cookery Sci. 21, 528-535.

25. Park, Y. S., Choi, Y. S., Hwang, K. E., Kim, T. K., Lee, C. W., Shin, D. M. and Han, S. G. 2017. Physicochemical Properties of Meat Batter Added with Edible Silkworm Pupae (Bombyx mori) and Transglutaminase. Korean J Food Sci Anim Resour. 37 (3), 351-359.

26. Pearson D. 1968. Application of chemical methods for the assessments of beef quality. J. Sci. Food Agri. 19: 366-369.

27. Rogar, P. J. and Robert, W. R. 1971. Effect of shelf temperatures, storage periods and rehydration solution on the acceptability and chemical composition of free-dried precooked commercially cured ham. J. Anim. Sci. 32, 624-629.

28. SAS. 1999. SAS/STAT Software for PC. Release 6.11, SAS Institute, Cary, NC, USA.

29. Tarladgis, B. G., Watts, B. M., Younathan, M. T. and Dugan, L. R. Jr. 1960. A distillation method for the quantitative determination of malonaldehyde in rancid food. J. Am. Oil Chem. Soc. 37: 44. 